\title{
SIMULATION OF EVACUATION FROM THE TERAZIJE TUNNEL
}

\author{
Radoje B. Jevtić \\ Secondary School of Electrical Engineering „Nikola Tesla“, \\ Niš, Republic of Serbia, \\ e-mail: milan.jvtc@gmail.com, \\ ORCID iD: (Dhttp://orcid.org/0000-0002-0179-1321
}

DOI: 10.5937/vojtehg67-20742; https://doi.org/10.5937/vojtehg67-20742

\author{
FIELD: Traffic \\ ARTICLE TYPE: Original Scientific Paper \\ ARTICLE LANGUAGE: English
}

\begin{abstract}
:
Evacuation presents a very complex and difficult task that implies the safest, shortest and fastest convoying of people, animals and material resources from an endangered object or location to a secure location. Different objects, different locations and different scenarios demand different evacuation strategies. One of very specific objects for evacuation is a road traffic tunnel. Because of the presence of a number of vehicles and people within limited space, road traffic tunnel evacuation can be an extremely unpredictable and dangerous task, which has already been confirmed by many accidents. There are also other aggravating circumstances such as tunnel length, fast spreading of smoke (especially of $\mathrm{CO}_{2}$ - carbon dioxide and CO- carbon monoxide) and fire in closed areas, limited options for approach to the accident place and many others, very often impossible to predict. One of very good, economical and safe ways for the prediction and analysis of evacuation situations and scenarios is the usage of simulation software. This paper has been written to show a simulation of evacuation from the road traffic tunnel at Terazije in Belgrade for different scenarios and for different speeds of participants.
\end{abstract}

Key words: evacuation, simulation, tunnel, traffic.

\section{Introduction}

Tunnels are underground or underwater (undersea) objects with both sides opened horizontally or with a slight gradient, designed for road traffic, railway traffic, water supply, etc. Depending on different factors (their position related to the ground, structure, applied building method, purpose, etc.), there are several different criteria to categorize tunnels. Their main purpose is to connect two different parts of the road separated by different obstacles. Modern tunnels for road traffic present real technological miracles equipped with the latest structural, electro 
technical, ecological and other solutions. They are equipped with modern light signalization, air and ventilation devices, sensors and detectors, cameras and a lot of other equipment that make drive through them simple, comfortable and, in the first place, safe. Many tunnels were built in a form of two "pipes", for traffic in both directions. In case of an accident, there are connection points where the traffic from the "pipe" where the accident occurred can be directed into the other "pipe". It is obvious that modern technology with its solutions increases safety in tunnels. The interior of a modern road traffic tunnel is presented in Figure 1 (Jevtić, 2014, pp.537-541), (Jevtić, 2016a, pp.754-768), (Jevtić, 2017, pp.98-114), (Grgić, 2008).

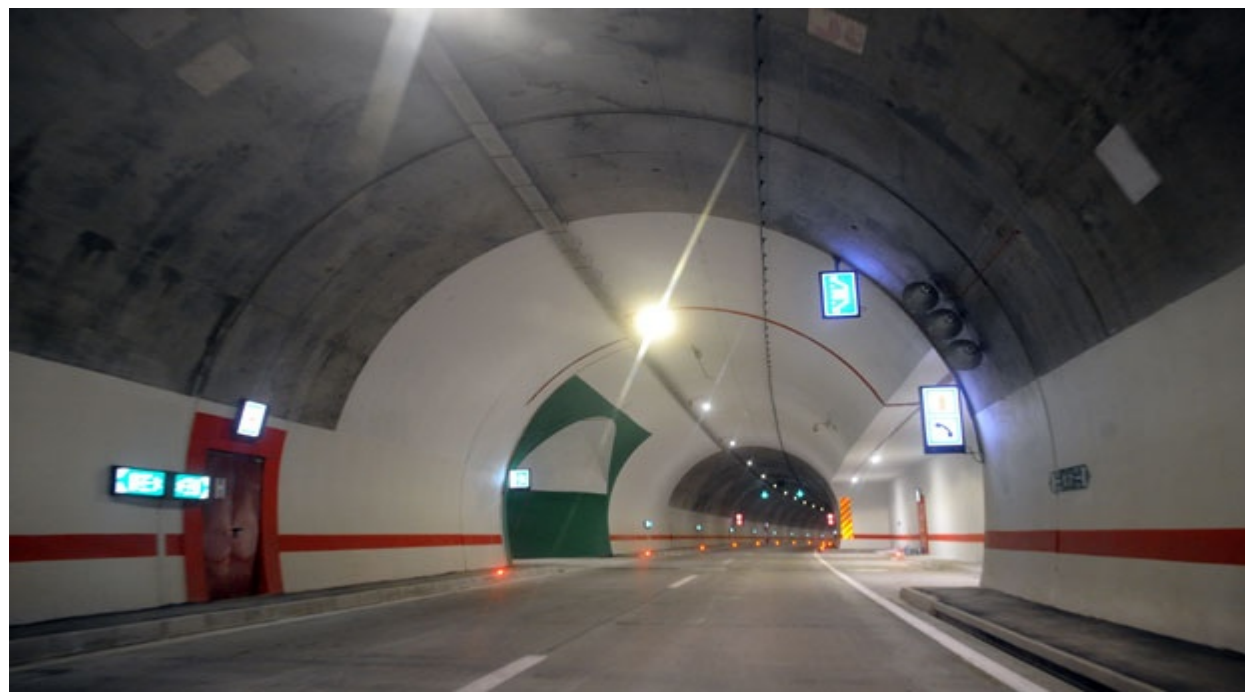

Figure 1 - The interior of a new road traffic tunnel on the Ljig-Preljina highway in Serbia (Radović, 2016)

Pис. 1 - Внутреннее обустройство тоннеля на автомагистрали Лиг-Прелина в Cербии (Radović, 2016)

Слика 1 - Унутрашњост новог друмског тунела на ауто-путу Љиг-Прељина у Србији (Radović, 2016)

However, tunnel characteristics, the number of vehicles with different dimensions, purposes and speeds, drivers' skills and drivers' health and psychological conditions, human behaviour during panic in closed areas and many other different factors make it almost impossible to completely eliminate accidents in tunnels. Many different sources state that, since 1949, there have been 36 big accidents in road traffic tunnels, 31 of them in Europe. There were more than 200 slightly and seriously injured in those accidents, while more than 100 people lost their lives, 
mostly from fire and gases. There were many calculations and simulations but it is still hard to completely predict fire and smoke behaviour in tunnels. Material damage was huge which was documented by the fact that most of them were closed for a long time after the accidents. Some examples of the biggest road traffic tunnel accidents are the accidents in the Mont Blanc Tunnel (France) and the Tauern Tunnel (Austria) in 1999, and in the St. Gotthard Tunnel (Switzerland) in 2001. These road traffic tunnel accidents took about 62 human lives (39 in Mont Blanc, 12 in Tauern and 11 in St. Gotthard), (Daeron \& Ruffin, 2000). The longest tunnels are intended for railway, but there are a lot of long tunnels for road traffic. The list of the longest road traffic tunnels is presented in Table 1.

Table 1 - The longest road traffic tunnels in the world (Automagazin, 2011)

Таблица 1 - Самые длинные автодорожные тоннели мира (Automagazin, 2011) Табела 1 - Најдужи друмски тунели на свету (Automagazin, 2011)

\begin{tabular}{|l|l|l|}
\hline The name of the tunnel & Location & Length $(\mathrm{km})$ \\
\hline Duplex A86 & France & 9.98 \\
\hline Platbutsch & Austria & 9.98 \\
\hline Gran Sasso D'italia & Italia & 10.14 \\
\hline Hida & Japan & 10.78 \\
\hline Yamate Tunnel & Japan & 10.94 \\
\hline Kanetsu & Japan & 11.1 \\
\hline Folgefonn & Norway & 11.1 \\
\hline Baojiashan & China & 11.2 \\
\hline Gudvangen & Norway & 11.43 \\
\hline Mount Blanc & France - Italia & 11.6 \\
\hline Diaplingi Tunnel & China & 12.23 \\
\hline Frejus & France-Switzerland & 12.87 \\
\hline Hsuehshan Tunnel & Taiwan & 12.87 \\
\hline Arlberg & Austria & 14 \\
\hline St. Gotthard Tunnel & Switzerland & 16.9 \\
\hline Qinling Zhongnanshan Tunnel & China & 18.04 \\
\hline Laerdal Tunnel & Norway & 24.51 \\
\hline
\end{tabular}


The Terazije Tunnel represents one of the busiest traffic spots in Belgrade where even the smallest traffic jam can bring a halt to the traffic through most of Belgrade. Designed by Ljubomir Porfirović and Milosav Vidaković, the Terazije Tunnel in Belgrade was completed in 1973 through the building that had already existed in that location. It was a building of the then-Union of Chambers of Commerce, the construction of which lasted from 1957 to 1960 . Since a tunnel had been planned before World War Two, the space for the tunnel entrance had been left in the building basement (Telegraf, 2013). In 1955, when architect Dimitrije T. Leko proposed a plan for the City Hall, there was a tunnel at Terazije clearly plotted in it (Nikolić, 2014).

The Terazije Tunnel has a length of $223 \mathrm{~m}$, a width of $13 \mathrm{~m}$ and a height of $5.5 \mathrm{~m}$. It is of strategic importance for the city's traffic functioning. Any kind of jam, accident or similar occurrence in it can cause major problems in traffic frequency in all nearest streets as well as in some streets further away. Many accidents, unfortunately, have shown and proved its great traffic importance. For example, in the accident in October 2015, there were 11 cars and a bus in a chain collision which caused a jam for several hours (Blic, 2015). In an accident in 1997, Spasoje Barišić from Batajnica drove his Porsche at $192.4 \mathrm{~km} / \mathrm{h}$ and caused deaths of three young people while three others were seriously injured. The direction ahead of and after the Branko's Bridge, the highperformance car, and violation of traffic laws enabled reaching such high speed. There were also cases with fire, as the one which occurred in 2013 when a Japan- donated city bus caught fire. Fortunately, there were no victims. This tunnel is regularly maintained and in case of an accident, traffic is mainly directed from Dečanska street to the Branko's Bridge, while vehicles coming from the Branko's Bridge are directed to alternative streets. Soon after this fire, there was another one of a private car, so these occurrences prompted questions about the Tunnel fire safety and safety in public traffic. According to Ivan Zarev, the then-Head of Direction for Prevention of the Emergency Management Sector of the Ministry of Interior of Serbia, many old objects built 30, 40 and more years before had "receivership" right for fire protection. These objects would probably not satisfy modern and stricter fire regulations. For example, the Terazije Tunnel does not meet the basic requirements for fire protection such as fire extinguishing devices, ventilation systems, hydrant network, etc. (Pressonline, 2013).

The tunnel is available only for vehicles; for pedestrians, pass is not allowed. Because of its location, the tunnel presents an important traffic connection between the old part of the town and New Belgrade via 
Brankova street. The Terazije Tunnel is presented on the map in Figure 2 and everyday's situation in the tunnel is given in Figure 3.

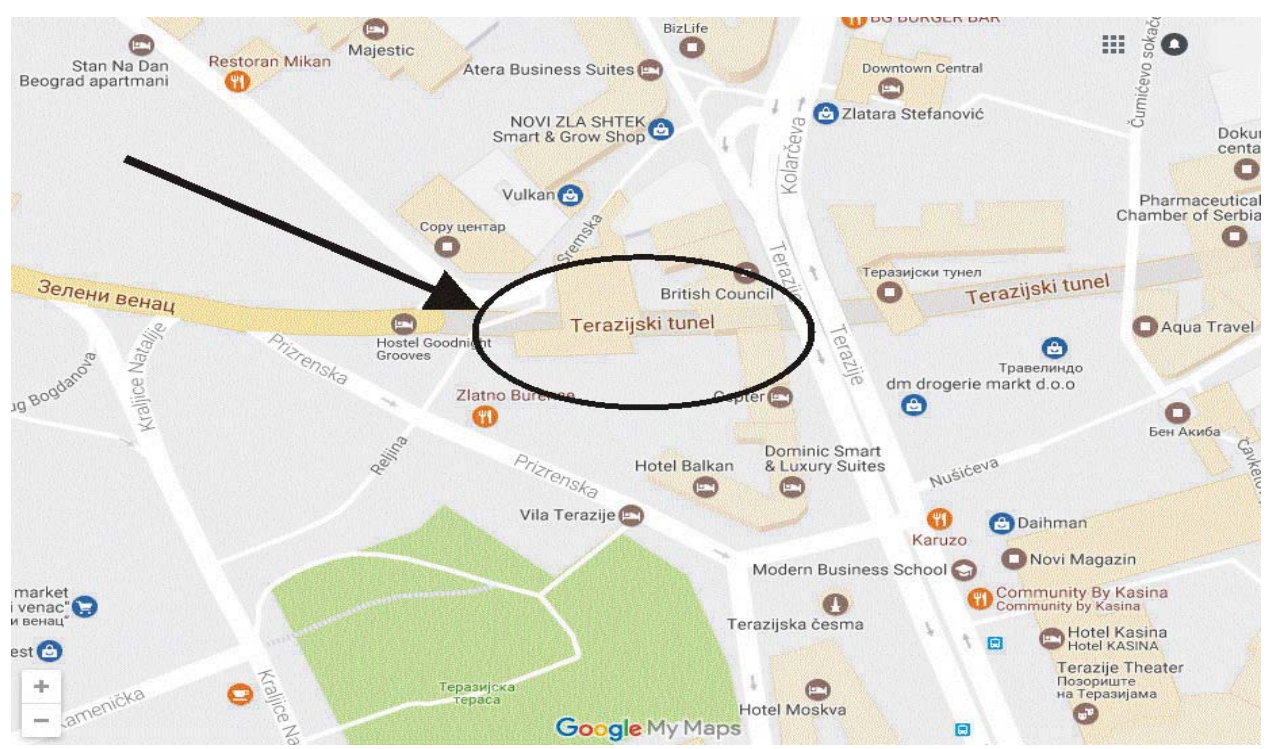

Figure 2 - Tunnel at Terazije, marked on the map of Belgrade

Puc. 2 - Тоннель „Теразие“, обозначен на карте Белграда

Слика 2 - Теразијски тунел означен на карти Београда

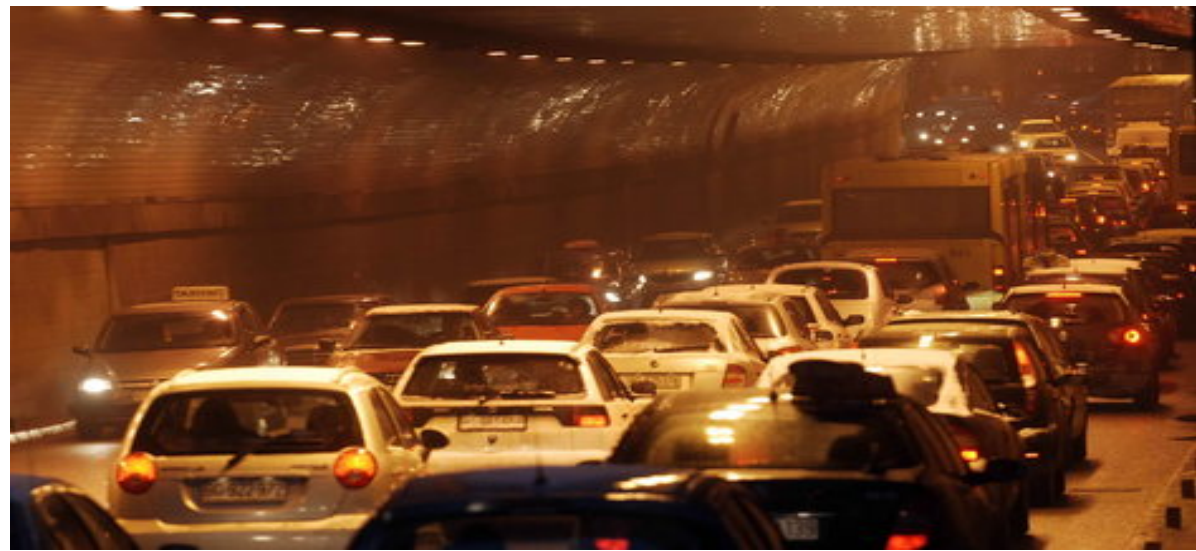

Figure 3-Every day's situation in theTerazije Tunnel Рис. 3 - Будни в тоннеле „Теразие“

Слика 3 - Свакодневни призор у Теразијском тунелу

It is, therefore, obvious that the Terazije Tunnel presents an important traffic factor in Belgrade and in the cases of its closure or blocking, there could be serious problems such as traffic collapse, people 
and goods transport disruptions and, most importantly, endangered human lives. So, it is necessary to predict potential situations that can cause traffic paralysis in the Tunnel and predict all needed time for people's evacuation. Timely evacuation of people presents the most important task in crisis situations and the most important contribution of this study. Evacuation prediction presents a very hard, complex and always open task, especially in specific situations such as those that can occur in tunnels. One of the best ways for evacuation prediction in terms of safety, accuracy, organisation, and low cost is a usage of simulation software. There are a lot of different evacuation software programs in the market. One of the most frequently used is Pathfinder.

This paper presents an example of prediction of specific evacuation situations in the Terazije Tunnel (collision and scrimmage) where such situations frequently occur. The results realized in this paper present the advantages of simulation software usage and much better potentials for the prediction of different evacuation situations thus enabling correct and safe prediction of evacuation procedures, calculation of evacuation times and a choice of the best evacuation route in terms of human safety.

\section{Simulation model}

The simulation model was designed in Auto Cad software in accordance with its real dimensions and transferred to Pathfinder 2012. Pathfinder 2012 presents special software developed as an evacuation simulator. In the market, there are several different simulators that can be used for evacuation purposes. Pathfinder provides a graphical user interface for simulation design and execution as well as 2D and 3D visualization tools for a results analysis which enables an evacuation presentation in every moment and at every location of the observed object (Thunderhead engineering, 2012).

The simulation was realized for different occupant speeds $(0.9 \mathrm{~m} / \mathrm{s}$, $1.1 \mathrm{~m} / \mathrm{s}, 1.3 \mathrm{~m} / \mathrm{s}, 1.7 \mathrm{~m} / \mathrm{s}, 2 \mathrm{~m} / \mathrm{s}, 2.5 \mathrm{~m} / \mathrm{s}, 3 \mathrm{~m} / \mathrm{s}, 3.5 \mathrm{~m} / \mathrm{s}, 4 \mathrm{~m} / \mathrm{s}$, and 4.5 $\mathrm{m} / \mathrm{s}$ ). Generally, occupants can achieve higher speeds than $4.5 \mathrm{~m} / \mathrm{s}$ but not in the limited area with other occupants and cars as obstacles. The occupants were positioned in their vehicles at the start of the simulation. In accordance with the postulated scenarios, the tunnel was full with different vehicles. There were 161 cars and 5 buses. Every car had 4 occupants inside and every bus had 60 occupants inside. The total number of occupants was 944 . The dimensions (length, width, height) of every car were $4.2 \mathrm{~m} \times 1.8 \mathrm{~m} \times 1.6 \mathrm{~m}$, while the dimensions of all buses were $13 \mathrm{~m} \times 2.65 \mathrm{~m} \times 3.2 \mathrm{~m}$. Every vehicle had a determined number of 
doors which means that cars had 4 exit doors and busses had 3 exit doors. The distance between every two vehicles was $0.9 \mathrm{~m}$. The vehicles were positioned in four separate lanes, two in one direction and two in the opposite direction. Similar evacuation models were realized in some earlier papers (Jevtić, 2016a, pp.754-768), (Jevtić, 2016b, pp.197-208), (Jevtić, 2017, pp.98-114).

There were two different simulation scenarios. The first simulation scenario involved a tunnel full with cars and buses but without any kind of collision, thus simulating a simple jam in the tunnel - almost an everyday occurrence. The second scenario also involved a tunnel full with cars and buses but with a collision. The collision between a bus and three cars was at $92 \mathrm{~m}$ after the Tunnel entrance from the side of Zeleni Venac. Of course, this evacuation model can be changed for different scenarios and conditions, which presents a good approach in simulating as realistic situations as possible and getting as accurate results as possible (Ronchi et al, 2012, pp.74-84), (Jevtić, 2016c, pp.35-48), (Galea, 2013). The vehicles in the tunnel for the first and the second scenario are presented in Figures 4 and 5.

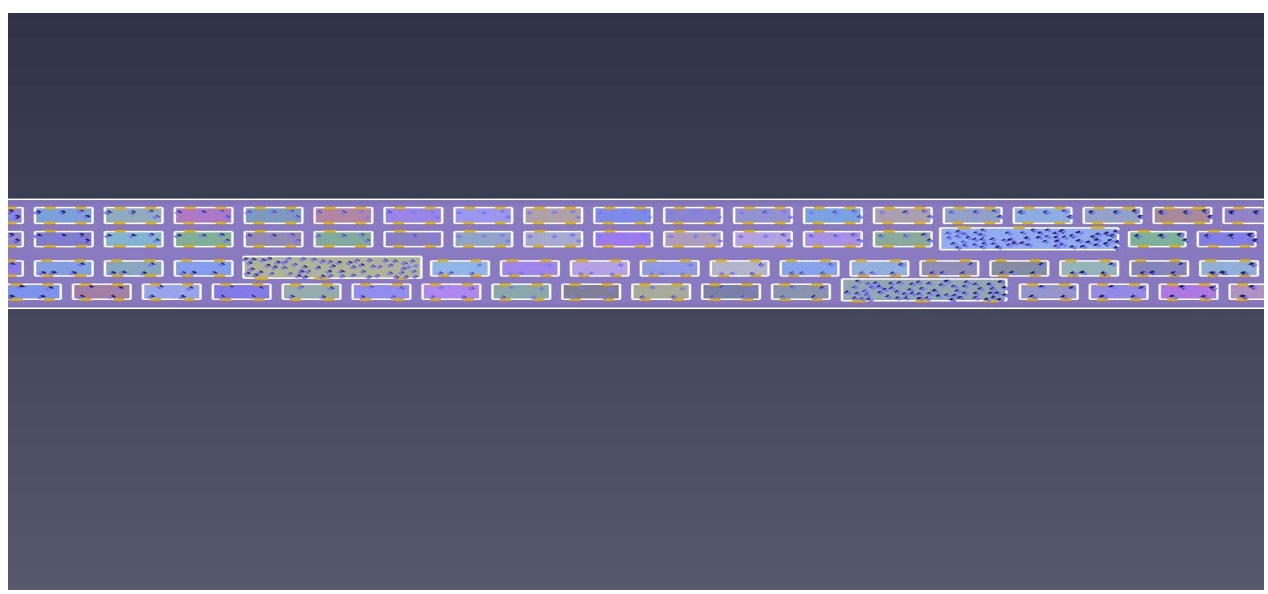

Figure 4 - Simulation presentation of a tunnel with vehicles and occupants inside (the first simulation scenario)

Puc. 4 - Презентация моделирования тоннеля с автомобилями и пассажирами внутри (первый сценарий модели)

Слика 4 - Симулација презентације тунела са возилима и путницима у њему (први сценарио симулације) 


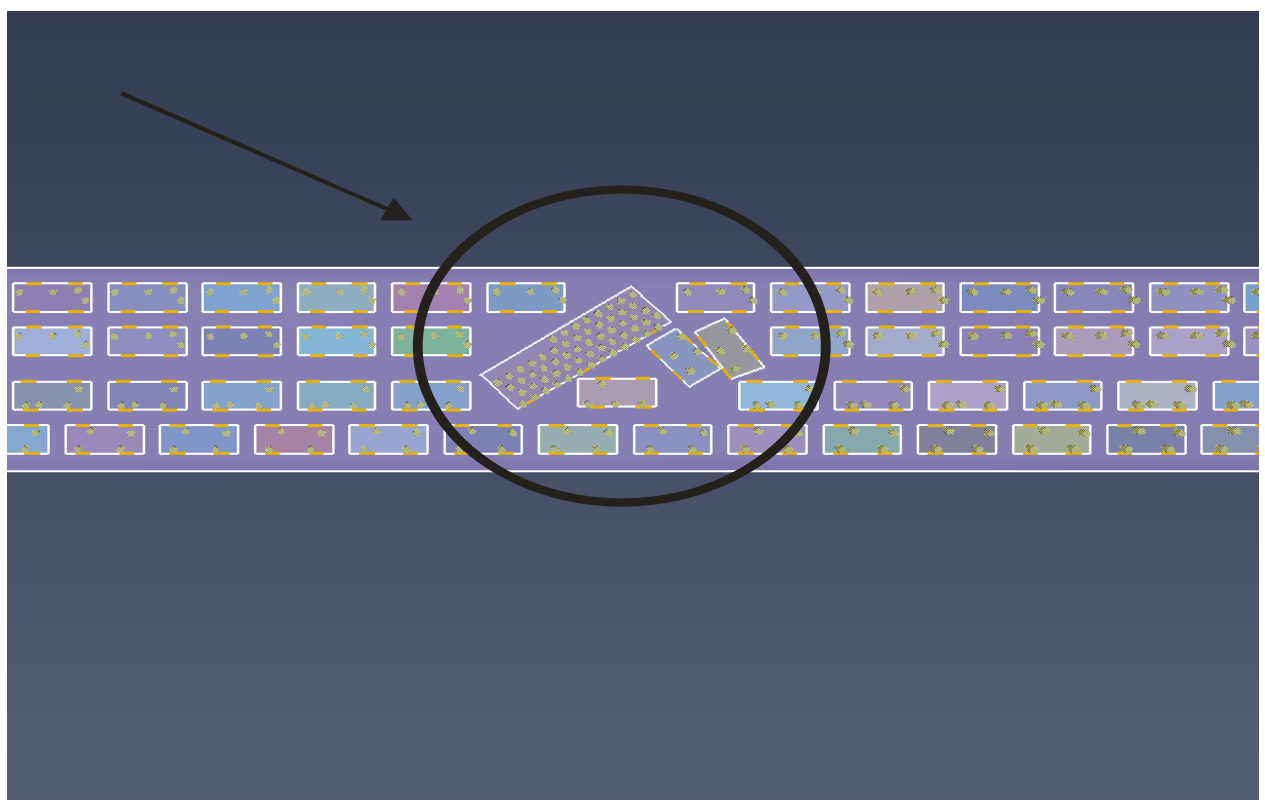

Слика 5 - Симулација презентације тунела са означеном позицијом судара (други сценарио симулације)

\section{Simulation results}

The simulations of the evacuation from the Terazije Tunnel were realized on a Lenovo ThinkPad L560 laptop, with Intel i7 $6600 \mathrm{U} 1.80 \mathrm{GHz}$ - 2.40ghz and 16 GB of RAM memory.

The average simulation time was about 15 minutes.

Some evacuation examples from the first scenario with the occupant speed of $1.1 \mathrm{~m} / \mathrm{s}$ are presented in Figures from 6 to 9 , while the complete simulation results for both scenarios are presented in Figures 10 and 11. 


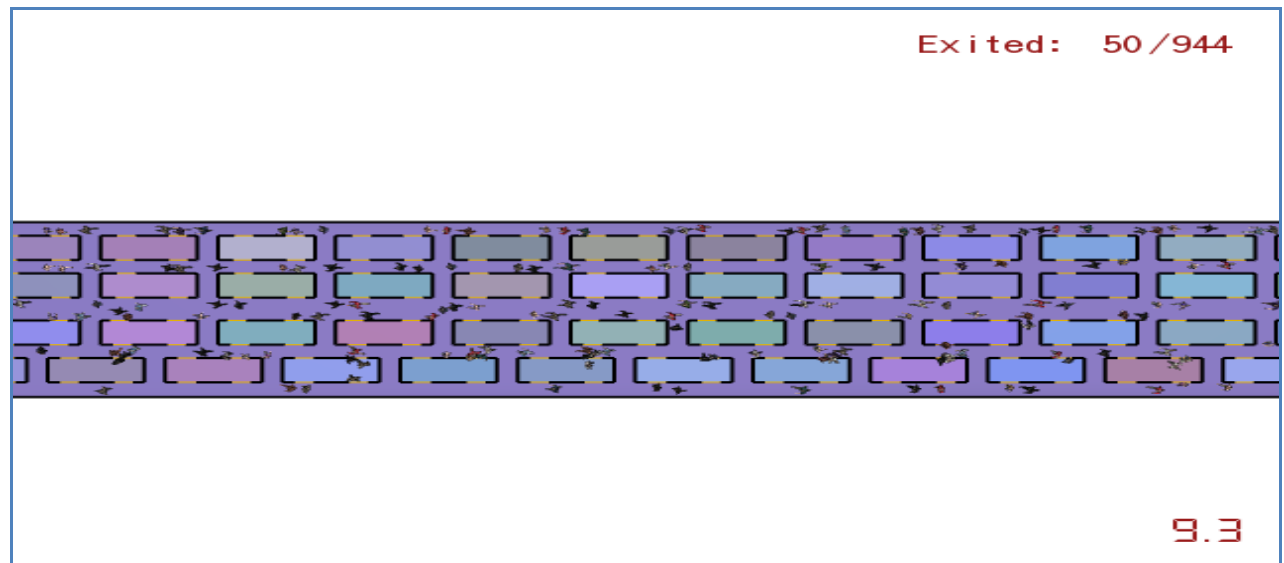

Figure 6 - Simulation example for the first scenario after 9.3 seconds from the start of the simulation

Puc. 6 - Модель по первому сценарию спустя 9,3 секунды от начала моделирования

Слика 6 - Пример симулације за први сценарио после 9,3 секунде од почетка симулације

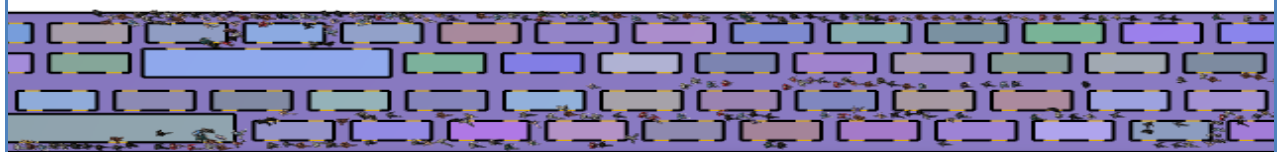

ㅋ․

Figure 7 - Simulation example for the first scenario after 39.6 seconds from the start of the simulation

Puc. 7 - Модель по первому сценарию спустя 39,6 секунд от начала моделирования

Слика 7 - Слика 7 - Пример симулације за први сценарио након 39,6 секунди од почетка симулације 


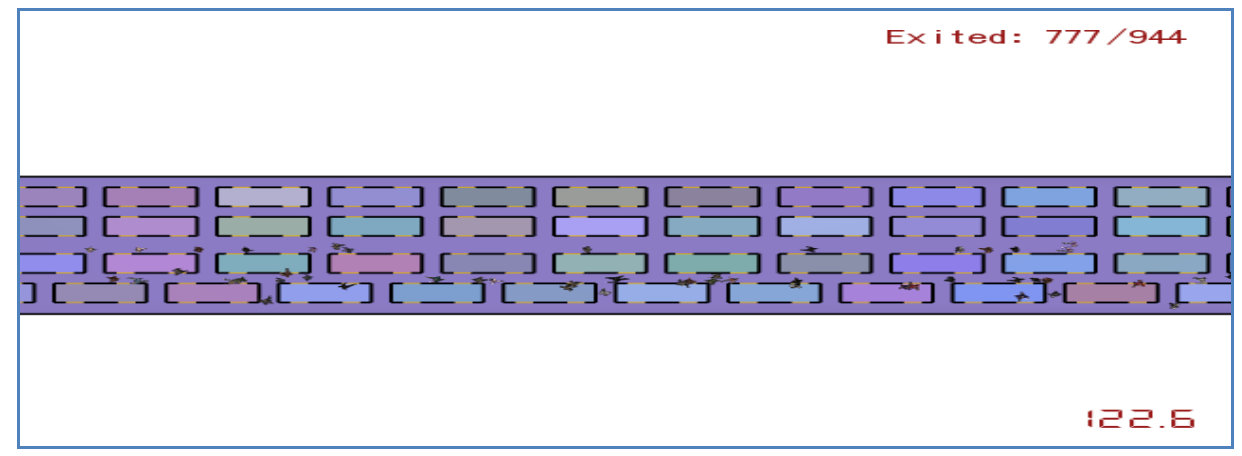

Figure 8 - Simulation example for the first scenario after 122.6 seconds from the start of the simulation

Puс. 8 - Модель по первому сценарию спустя 122,6 секунд от начала моделирования

Слика 8 - Пример симулације за први сценарио после 122,6 секунди од почетка симулације

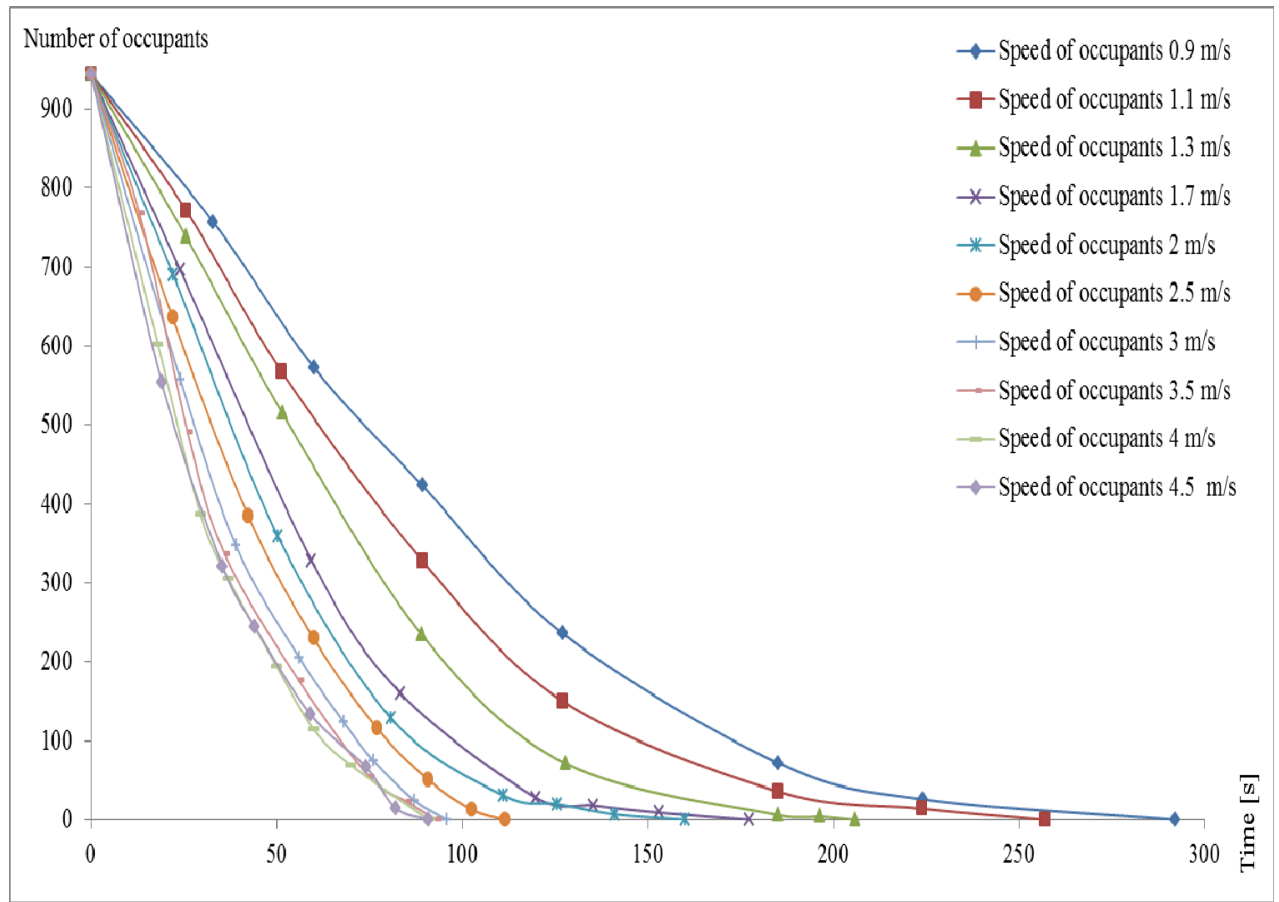

Figure 9 - Complete simulation results for the first scenario Puс. 9 - Результаты моделирования по первому сценарию Слика 9 - Комплетни резултати симулације за први сценарио 


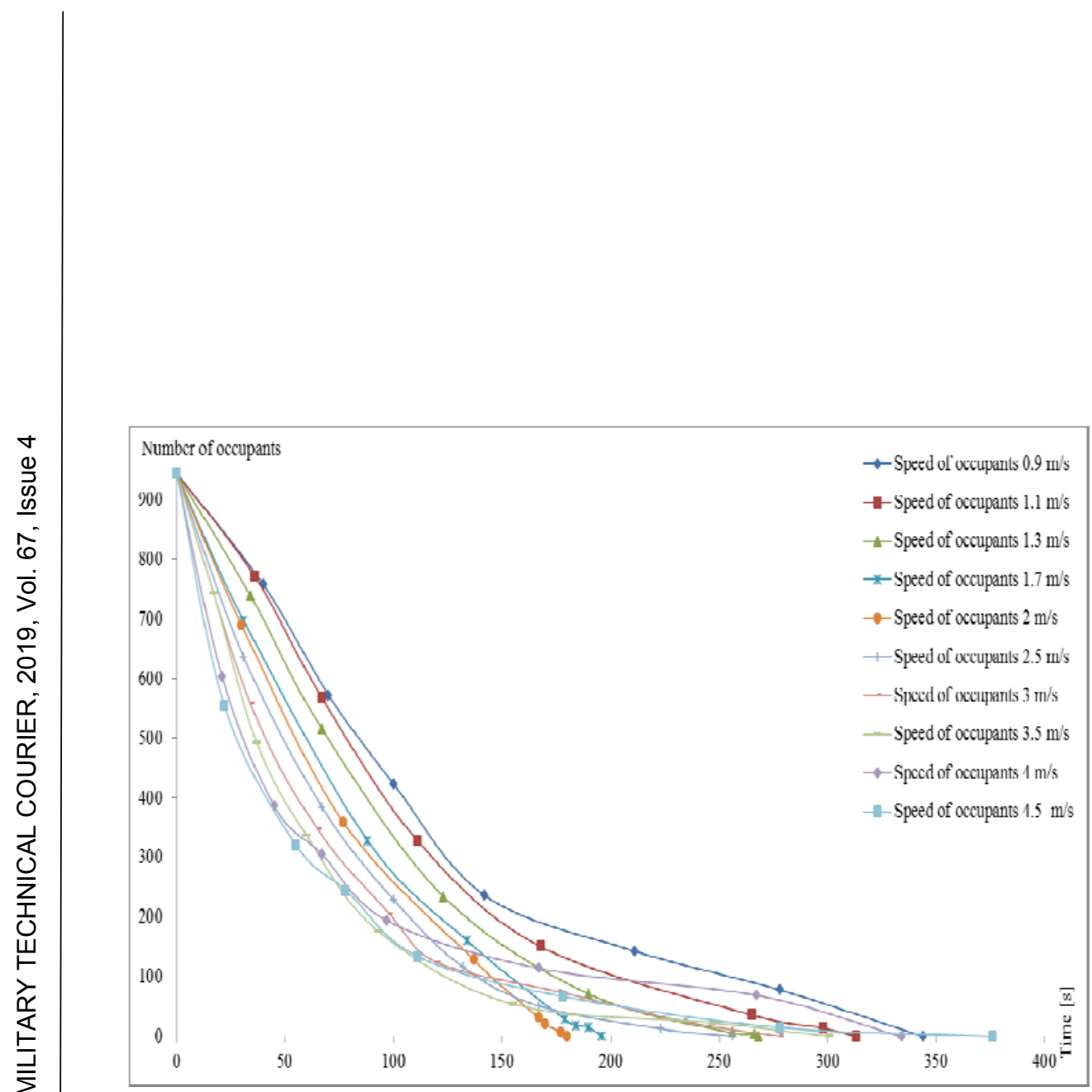

Figure 10 - Complete simulation results for the second scenario Puс. 10 - Результаты моделирования по второму сценарию Слика 10 - Комплетни резултати симулације за други сценарио

\section{Analysis of the results}

The results presented in Figure 9 show the times needed for complete evacuation of the occupants from the Tunnel in the first scenario. It is obvious that the faster occupants moved, the shorter evacuation times were. Although the occupant movement speeds were up to $4.5 \mathrm{~m} / \mathrm{s}$, that fact did not cause jams that could significantly increase the total evacuation time. The evacuation times were from 98.8 seconds to 292 seconds. It is also important to note that the realized simulation results did not take into account the influence of different gasses that could be emitted by car and bus exhaust systems generally, the tunnel as a pass is forbidden for pedestrians, but in case of some long jams or serious accidents (hold-ups of more than several hours) it is obvious that occupants of vehicles must, in order to save themselves, leave their vehicles and try to find the nearest exit. It is usual that occupants stay in their vehicles with closed doors and windows in case of short jams (several dozens of minutes).

The results presented in Figure 10 show the times needed for complete occupant evacuation from the Tunnel in the second scenario. In 
this case, the presence of collision consequences such as jams, for example, caused that the fastest occupant movements $(4.5 \mathrm{~m} / \mathrm{s}$ and 4 $\mathrm{m} / \mathrm{s}$ ) had the longest evacuation times. The evacuation time for the occupant speed of $4.5 \mathrm{~m} / \mathrm{s}$ was 376 seconds, the evacuation time for the occupant speed of $4 \mathrm{~m} / \mathrm{s}$ was 334 seconds, while the occupant speed of $0.9 \mathrm{~m} / \mathrm{s}$ was 344 seconds. The realized simulation results did not take into account the influence of different gasses on occupants either. For some slightly higher speeds of occupants, related to the realized results, the evacuation times would probably be significantly longer. Significantly higher speeds of occupants than the realized ones could not be achieved because of several reasons such as crowds, lack of space, and panic among occupants with uncontrolled behaviour. The realized simulations presumed that all occupants were the same (in terms of height, width and speed), which in some real situations undoubtedly is not the case. In addition, the simulations did not include situations where people with different disabilities participate in evacuation, when it is also very hard to predict and determine evacuation times, routes, ways and many other important factors, even with simulation software (Jevtić, 2014, 537-541), (Jevtić, 2015a, pp.45-52), (Jevtić, 2015b, pp.545-550), (Wilson, 2015, pp.48-50). It is important to note that speeds from $3 \mathrm{~m} / \mathrm{s}$ and higher are hard to achieve in the given circumstances so that they mostly have theoretical significance.

This and similar papers are a good basis for potential future investigations related to evacuation and risk analyses, where evacuation could include some other important factors such as smoke and fire directions, smoke quantity (especially $\mathrm{CO}_{2}, \mathrm{CO}$ and other toxic gasses), different types of collisions, and others (Persson, 2002).

\section{Conclusion}

It is very hard and almost impossible to control and predict all of the parameters that road tunnel evacuation depends on. The impossibility of controlling fire and human behaviour in panic is what supports the above mentioned statement. That is the reason why particular evacuation software must be used as an important and permanent engineering tool, even in the situations when this tool is not in a position to describe or simulate completely realistic situations. Different simulation results for different scenarios present the answers or ways that show how to find a solution for a particular problem if the calculation itself does not present the solution. So, this kind of software enables many different evacuation situations to be predicted and, based on the calculated evacuation times, 
the determination of the best evacuation route. This means the determination of the shortest and the safest way for people's evacuation. Also, one of the most important characteristics of this kind of evacuation prediction is a potential for fast and accurate testing and comparison of different evacuation models.

The future steps in this and similar studies should be taking into account some effects that can occur in this and similar situations such as smoke, fire, panic, obstacle avoidance and surmounting, help to others, calculation of evacuation times and determination of evacuation routes in cases when caring affected humans, etc.

This paper has been written to show the possibilities of the Terazije Tunnel evacuation prediction for different scenarios although some parameters or facts have not been included. This and similar software should and must become an obligatory engineer's tool in order to solve this kind of problems. Also, this and similar software must be permanently improved with new facts and knowledge (Jevtić, 2014, 537541), (Jevtić, 2015a, pp.45-52), (Jevtić, 2015b, pp.545-550), (Jevtić, 2016a, pp.754-768), (Jevtić, 2016b, pp.197-208), (Jevtić, 2016c, pp.3548), (Jevtić, 2017, pp.98-114).

\section{References}

-Automagazin. 2011. Najduži tuneli na svetu. Automagazin, 15 April [online]. Available at: http://www.automagazin.rs/vesti/\%209198/najduzi-tunelina-svetu (in Serbian) [Accessed: 22 July 2019].

-Blic. 2015. LANČANI SUDAR Sudarilo se čak JEDANAEST vozila $i$ autobus $\mathrm{u}$ terazijskom tunelu. Blic, 6 October [online]. Available at: https://www.blic.rs/vesti/beograd/lancani-sudar-sudarilo-se-cak-jedanaest-vozilai-autobus-u-terazijskom-tunelu/e18lvjw (in Serbian) [Accessed: 22 July 2019].

Daeron, S., \& Ruffin, E. 2000. Calculations for fire smoke behaviour in long rail tunnels. In: 1. International Conference "Tunnels and Underground Station Fires", Hong Kong, May. Available at: https://hal-ineris.archivesouvertes.fr/ineris-00972196/document.

Galea, R.E. 2013. The Development and Validation of a Rail Car Evacuation Model. In: 13th International Conference and Exhibition on Fire Science and Engineering INTERFLAM 2013, Nr Windsor, UK, pp.1013-1034, June 24-26.

Grgić, I. 2008. Specifičnosti geodetske osnove. Zagreb: University of Zagreb - Faculty of Geodesy. Master thesis (in Serbian).

Jevtić, B.R. 2014. Simulation of the shopping centre Zona I evacuation. Tehnika - Elektrotehnika, 3, pp.537-541.

Jevtić, B.R. 2015a. The evacuation possibilities of sanitary objects. Zdravstvena zaštita, 44(6), pp.45-52. 
Jevtić, B.R. 2015b. The simulation of sanitary objects evacuation-an example of hotel Radon in Niška Banja. Tehnika - Elektrotehnika, 3, pp.545-550.

Jevtić, B.R. 2016a. Evacuation from tunnels: An example of the Straževica tunnel. Vojnotehnički glasnik/Military Technical Courier, 64(3), pp.754-768. Available at: https://doi.org/10.5937/vojtehg64-9378.

Jevtić, B.R. 2016b. Security in metro: An example for simulation ofevacuation from subway. Facta universitatis - series: Working and Living Enviromental Protection, 13(3), pp.197-208.

Jevtić, B.R. 2016c. Simulation of evacuation situations in order to protect human lives and material property. NBP Žurnal za kriminalistiku i pravo, 21(2), pp.35-48. Available at: https://doi.org/10.5937/nbp1602035J.

Jevtić, B.R. 2017. The safety in tunnels: An example of simulated evacuation from a railway tunnel. Bezbednost, 59(1), pp.98-114. Available at: https://doi.org/10.5937/bezbednost1701098J.

Nikolić, Z. 2014. Metropola se rodila tokom noći. Večernje novosti, 18 December 2014 [online]. Available at: http://www.novosti.rs/vesti/beograd.74.html:524650-Metropola-se-rodila-tokomnoci (in Serbian) [Accessed: 22 July 2019].

Persson, M. 2002. Quantitative risk analysis procedure for the fire evacuation of a road tunnel. Lund: Lund University, Department of Fire Safety Engineering, Sweden. ISSN 1402-3504.

-Pressonline. 2013. GSP: Autobus se sam zapalio u Terazijskom tunelu. Pressonline, 8 October [online]. Available at: http://www.pressonline.rs/info/beograd/288288/gsp-autobus-se-sam-zapalio-uterazijskom-tunelu.html (in Serbian) [Accessed: 22 July 2019].

Radović, Z. 2016. PATROLA "NOVOSTI": Od Ljiga do Preljine za manje od pola sata. Večernje novosti, 18 November [online]. Available at: http://www.novosti.rs/vesti/naslovna/ekonomija/aktuelno.239.html:633679-

PATROLA-NOVOSTI\%20-Od-Ljiga-do-Preljine-za-manje-od-pola-sata-FOTO (in Serbian) [Accessed: 22 July 2019].

Ronchi, E., Colonna, P., Capote, J., Alvear, D., Berloco, N., \& Cuesta, A. 2012. The evaluation of different evacuation models for assessing road tunnel safety analysis. Tunneling and Underground Space Technology, 30, pp.74-84. Available at: https://doi.org/10.1016/j.tust.2012.02.008.

-Telegraf. 2013. TELEGRAFOV VREMEPLOV: Beograd bez Terazijskog tunela. Telegraf, 12 May [online]. Available at: https://www.telegraf.rs/vesti/beograd/692481-telegrafov-vremeplov-beogradbez-terazijskog-tunela-foto (in Serbian) [Accessed: 22 July 2019].

-Thunderhead engineering. 2012. Pathfinder User Manual [online] Available at: https://www.thunderheadeng.com/files/net/pathfinder-2012docs/users guide.pdf [Accessed: 21 July 2019].

Wilson, L. 2015. Planing for evacuation people with disability. IFPInternational Fire Protection Magazine, 61, March, pp.48-50. Available at: https://drive.google.com/file/d/0Bx8esUt9L_HdYU1UejU5SXFoYVE/view [Accessed: 21 July 2019]. 


\section{МОДЕЛИРОВАНИЕ ЭВАКУАЦИИ ИЗ ТОННЕЛЯ «ТЕРАЗИЕ»}

\section{Радое Б. Евтич}

Электротехнический техникум «Никола Тесла»,

г. Ниш, Республика Сербия

РУБРИКА ГРНТИ: 73.31.17 Организация и безопасность дорожного движения

ВИД СТАТЬИ: оригинальная научная статья

ЯЗЫК СТАТЬИ: английский

\section{Резюме:}

Эвакуация представляет собой чрезвычайно сложный $и$ многогранный процесс, подразумевающий перемещение людей, животных и имущества из охваченного чрезвычайной ситуацией объекта или местности в безопасную зону. Различные объекты, местность или сценарии требуют и подразумевают различные соответствующие меры эвакуационной стратегии. Одним из специфических объектов для эвакуации является автодорожный тоннель. Из-за большого количества автомобилей и людей, находящихся в ограниченном пространстве, эвакуация в автодорожном тоннеле может оказаться чрезвычайно непредсказуемым и опасным заданием, о чем свидетельствует большое количество произошедших несчастных случаев. В данной связи при моделировании необходимо предусмотреть такие непредвиденные обстоятельства как: больщая длина тоннеля, стремительное распространение дыма (особенно $\mathrm{CO}_{2}$ - оксид углерода и СО - моноксид углерода) и пожар в закрытом пространстве, ограниченные возможности доступа к месту аварии и многие другие, зачастую непредсказуемые обстоятельства. Одним из целесообразных и надежных методов прогнозирования и анализа эвакуационных обстоятельств и мероприятий является разработка сценарного моделирования эвакуационных ситуаций с помощью программного обеспечения. Целью данной работы было описание эвакуационных мероприятий в автодорожном тоннеле «Теразие» в городе Белград. Программным обеспечением были охвачены разные сценарии, с учетом различного количества участников и скорости автодорожного движения.

Ключевые слова: эвакуация, моделирование, тоннель, транспорт. 
СИМУЛАЦИЈА ЕВАКУАЦИЈЕ ИЗ ТЕРАЗИЈСКОГ ТУНЕЛА

Радоје Б. Јевтић

Електротехничка школа „Никола Тесла”, Ниш, Република Србија

ОБЛАСТ: саобраћај

ВРСТА ЧЛАНКА: оригинални научни рад

ЈЕЗИК ЧЛАНКА: енглески

Сажетак:

Евакуација представља веома комплексан и тежак задатак који имплицира најбезбедније, најкраће и најбрже премештање људи, животиња и материјалних добара из угроженог објекта или локације до сигурне локације. Различити објекти, локације или сценарији захтевају и подразумевају различите адекватне евакуационе стратегије. Један од веома специфичних објеката за евакуацију је тунел за друмски саобраћај. Због присуства мноштва возила и људи на ограниченом простору, евакуација тунела за друмски саобраћај може бити екстремно непредвидив и опасан задатак, што потврђује велики број несрећа који се десио. Такође, постоје и друге околности, као што су потенцијално велика дужина тунела, брзо ширење дима (посебно $\mathrm{CO}_{2}$ и CO ) и ватре у затвореним просторима, ограничене могућности за приступ месту несреће и многе друге које је често немогуће предвидети. Један од веома добрих, економичних и сигурних начина за предвиђање и анализу евакуационих ситуација и сценарија јесте употреба симулационог софтвера. У раду је приказана евакуација из тунела за друмски саобраћај на Теразијама у Београду, за различите сценарије и различите брзине учесника.

Кључне речи: евакуација, симулација, тунел, саобраћај.

Paper received on / Дата получения работы / Датум пријема чланка: 26.02.2019. Manuscript corrections submitted on / Дата получения исправленной версии работы / Датум достављања исправки рукописа: 22.07.2019.

Paper accepted for publishing on / Дата окончательного согласования работы / Датум коначног прихватања чланка за објављивање: 24.07.2019.

(C) 2019 The Author. Published by Vojnotehnički glasnik / Military Technical Courier (www.vtg.mod.gov.rs, втг.мо.упр.срб). This article is an open access article distributed under the terms and conditions of the Creative Commons Attribution license (http://creativecommons.org/licenses/by/3.0/rs/).

() 2019 Автор. Опубликовано в «Военно-технический вестник / Vojnotehnički glasnik / Military Technical Courier» (www.vtg.mod.gov.rs, втг.мо.упр.срб). Данная статья в открытом доступе и распространяется в соответствии с лицензией «Creative Commons» (http://creativecommons.org/licenses/by/3.0/rs/).

(c) 2019 Аутор. Објавио Војнотехнички гласник / Vojnotehnički glasnik / Military Technical Courier (www.vtg.mod.gov.rs, втг.мо.упр.срб). Ово је чланак отвореног приступа и дистрибуира се у складу са Creative Commons licencom (http://creativecommons.org/licenses/by/3.0/rs/).

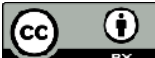

